\title{
A Study of the Determination of the Heat of Hydration of Portland Cement
}

\author{
By Edwin S. Newman
}

\begin{abstract}
Three relatively inexperienced operators made six determinations each of the heat of hydration of a sample of portland cement. The results of their measurements were calculated by the method described in Federal Specification SS-C-158b and by two simpler reducedobservation methods. By statistical analysis, no significant differences were found among either operators or methods. The precision (standard deviation of a single determination) of the heat-of-hydration measurements was about 3 calories per gram at 7 days and 2 calories per gram at 28 days. Somewhat better precision can be expected from experienced operators.
\end{abstract}

\section{Introduction}

The heat-of-solution procedure for determining the heat of hydration of portland cement has been a part of the federal specification [1] ${ }^{1}$ for a number of years. More recently, the method has been accepted by the American Society for Testing Materials [2]. Excepting a paper by Shartis and Newman [3], there has been little published on its precision.

The method depends upon the determination of the heat of solution in acid of a cement and of a hardened paste made therefrom. The difference between these values is approximately the heat evolved during the preparation and hardening of the paste and is very nearly equal to the true heat of hydration of the cement. ${ }^{2}$ Auxiliary determinations of the ignition losses of the cement and of the hardened paste are required to determine the quantity of ignited cement represented by a weighed amount of the hardened paste. Heats of solution and hydration are given in this paper on the basis of the weight of ignited cement.

For low apparatus cost and for simplicity in operation, the calorimeter chosen for the routine acceptance testing of cement [4] consisted of a 1-pint vacuum flask and a Beckmann thermometer with a reading lens, together with a motor-driven stirrer. This calorimeter was to be operated in an ordinary laboratory with only superficial protection from changes in the ambient temperature. The difficulties that exist in making determinations with this calorimeter arise in large part from the fact that there is in the cork and the glass of the flask considerable material with a low thermal conductivity and a relatively large heat capacity. This material is at an indeterminate temperature between that of the room and that within the calorimeter, and when the liquid temperature is suddenly changed several degrees, as in a heat-of-solution determination, the lag caused by its presence in the path of heat flow interferes with the determination of the amount of

\footnotetext{
1 Figures in brackets indicate the literature references at the end of this paper. 2 The heat of hydration defined as the difference between the two heats of solution ignores the heat of solution of the water contained in the paste, amounting to approximately $0.1 \mathrm{cal} / \mathrm{g}$ of cement. The effect of the absorption of $\mathrm{CO}_{2}$ during the grinding of the paste is also ignored.
}

heat lost to or gained from the surroundings. This interference has led to some doubt that the application of methods of precise calorimetry embodied in the specification procedure is entirely valid.

The original method for the heat-of-solution determination was somewhat oversimplified [4]. The precision necessary in this test is somewhat greater than appears at first glance. It is required to determine the heat of solution of a dry cement, amonuting to approximately $600 \mathrm{cal} / \mathrm{g}$, and the heat of solution of the corresponding hardened paste, 520 to 550 $\mathrm{cal} / \mathrm{g}$, with such precision that their difference, the heat of hydration of the cement, can be considered reliable to a few calories per gram. If a precision (standard deviation) of $2.0 \mathrm{cal} / \mathrm{g}$, not an impressive value, is desired in the heat-of-hydration determination, a precision of $1.4 \mathrm{cal} / \mathrm{g}(2.0 / \sqrt{2})$ is required in each of the individual heat-of-solution tests. This amounts to a precision of approximately 0.25 percent, a value not easily reached consistently in routine calorimetry with relatively crude apparatus.

In an effort to improve the precision, and partly as a result of work at the Bureau [3], the original method was revised [1], primarily to allow more time for the calorimeter to establish constant operating conditions during the test and also to introduce a correction allowing for the time required to dissolve the sample. The effect of the revision was to substantially extend the time required for the test and to demand somewhat more attention by the operator. The procedure requires the recording of timetemperature data during two rating periods, one before and one after the period during which the sample is being dissolved. The temperature of the surroundings is assumed constant, and the thermalleakage constant is calculated from these data taken when the rates of temperature change of the calorimeter depend only on the flow of heat to or from the room and on the energy of stirring. Besides the readings at 5 -min intervals required by the original method, four additional readings are taken at 1-min intervals during the first part of the solution period. These data permit the approximate correction of the observed temperature rise of the calorimeter for the energy received from the surroundings and for the 
energy of stirring and evaporation. These details are in accordance with precision calorimetry in which an isothermal jacket is employed.

It has been suggested that some of these revisions could be omitted without seriously affecting the value of the calorimetric test. From an examination of routine test data, it appeared to the author that excluding all the observations taken during the solution period from the calculations would cause a systematic error of possibly $+1 \mathrm{cal} / \mathrm{g}$ in the value for the heat of hydration. The precision of $2.0 \mathrm{cal} / \mathrm{g}$ suggested in an earlier paragraph implies that one-third of the tests will differ by more than $2 \mathrm{cal} / \mathrm{g}$ from the true (unknown) value. In other words, with an acceptance value of $80 \mathrm{cal} / \mathrm{g}$, one-third of the samples with an actual heat of hydration of $82 \mathrm{cal} / \mathrm{g}$ will be accepted, and one-third of the samples with a heat of hydration of $78 \mathrm{cal} / \mathrm{g}$ will be rejected. Only when the true heat of hydration is below $75 \mathrm{cal} / \mathrm{g}$ will the cement be almost certain to pass the acceptance test. Only when the true value is above $85 \mathrm{cal} / \mathrm{g}$ will the cement be almost certain to be rejected. In the light of this uncertainty it would appear that a systematic error of $+1 \mathrm{cal} / \mathrm{g}$ could be permitted. The test could then be considerably simplified, although the time required for its performance could not safely be shortened.

If this apparent systematic error can be tolerated, it is possible to eliminate the preliminary 5 -min rating period (distinct from the preliminary 20-min stirring period), to reduce the number of observations, and to avoid much of the calculation. In this suggested procedure only three readings of time and temperature are required, one at the end of the preliminary stirring period just before the introduction of the sample, one at the end of the solution period, and one subsequently to establish the final rate of temperature change. It is necessary to extend the solution period sufficiently to insure the calorimeter's return to a steady state, after complete solution of the sample, before the second temperature is recorded. The time between the second and third readings of the temperature is the rating period. If the solution and rating periods are of the same length, the calculation of the corrected temperature is simple. The difference between the first two readings is the uncorrected rise. The difference between the second and third readings is the correction to be added or subtracted according to whether the calorimeter temperature falls or rises during the rating period. If the two periods differ in length, the observed correction is adjusted to correspond to the duration of the solution period. During the interval between readings, the operator's time can be utilized to operate a second calorimeter, or for any other purpose not requiring undivided attention. The reduced-observation method was used in the investigation reported by Shartsis and Newman [3]. The temperature of the calorimeter was recorded at 0,20 , and $40 \mathrm{~min}$ for the determinations presented in their paper. It is this author's belief that $20 \mathrm{~min}$ may sometimes be too short for a solution period, and it is suggested that the reduced-observation method be performed by taking readings at the end of the preliminary stirring period and twice thereafter at intervals of $25 \mathrm{~min}$. A comparison of reducedobservation methods with the specification method of performing the heat-of-hydration test is a purpose of this paper.

\section{Materials, Apparatus, and Procedure}

A calorimeter meeting the requirements of the Federal Specification [1] was used. Three operators were available: $\mathrm{A}$, with a moderate amount of experience; $\mathrm{B}$, with a small amount; and $\mathrm{C}$, with a few days. Approximately 50 liters of $2.00 \quad \mathrm{~N} \mathrm{HNO}_{3}$ were prepared and standarized. This quantity was sufficient for the entire series of tests, and thereby uncertainties were avoided that might be introduced by the use of different batches of acid.

Three kilograms of Type 2 cement (moderate heat of hardening) were mixed for several hours in a laboratory ball mill containing a few pebbles, divided into three portions, and stored in tightly closed Mason jars. The portions were numbered 1, 2, and 3 , and each portion was assigned to an operator. Each operator mixed a paste from each portion according to the procedure described in the Federal Specification [1].

The three operators each determined the heat capacity [1] of the calorimeter three times. In addition, during the time before the 7-day heat-ofsolution test, each operator made a single determination of the heat of solution of each of the three portions of dry cement. At 7 days and again at 28 days, each operator determined the heat of solution of the three hydrated pastes made from the one portion of cement assigned to him. Thus each operator determined the heat of solution of paste samples prepared from one portion of cement by himself and by each of the other operators. This entire series of tests was repeated, so that each determination was made twice. The entire elapsed time during the tests was about 6 weeks.

\section{Results and Discussion}

The results of the heat-capacity and heat-ofsolution tests are given in table 1 , calculated as described in the specification [1]. In addition, the calorimetric observations were used in calculating the test results by two reduced-observation methods. Table 1 also shows these values as calculated from temperature readings taken at 0,20 , and $40 \mathrm{~min}$ and at 0,25 ; and $50 \mathrm{~min}$, respectively. Throughout the tables and the paper these reduced-observation methods will be called 0-20-40 and 0-25-50 methods. The heat capacities appearing in the table and used in calculation of the heats of solution were calculated in the same manner as the heat-of-solution values for which they were used. 
TABLE 1. Heat capacity of the calorimeter and heats of solution and hydration of a sample of portland cement

[The average heat capacity of the three values determined by each operator during a round was used to calculate that operator's heats of solution for that round]

\begin{tabular}{|c|c|c|c|c|c|c|c|c|c|c|c|c|c|c|c|c|c|c|c|}
\hline \multirow{3}{*}{$\begin{array}{c}\text { Paste } \\
\text { mixed } \\
\text { by }\end{array}$} & \multirow{3}{*}{$\begin{array}{l}\text { Calorim- } \\
\text { eter } \\
\text { operator }\end{array}$} & \multicolumn{6}{|c|}{ Specification method a } & \multicolumn{6}{|c|}{$0-20-40$ method $b$} & \multicolumn{6}{|c|}{$0-25-50$ method $c$} \\
\hline & & \multirow{2}{*}{$\begin{array}{l}\text { Heat } \\
\text { capac- } \\
\text { ity }\end{array}$} & \multicolumn{3}{|c|}{ Heat of solution } & \multicolumn{2}{|c|}{$\begin{array}{c}\text { Heat of } \\
\text { hydration } d\end{array}$} & \multirow{2}{*}{$\begin{array}{l}\text { Heat } \\
\text { capac- } \\
\text { ity }\end{array}$} & \multicolumn{3}{|c|}{ Heat of solution } & \multicolumn{2}{|c|}{$\begin{array}{c}\text { Heat of } \\
\text { hydration } d\end{array}$} & \multirow{2}{*}{$\begin{array}{l}\text { Heat } \\
\text { capac- } \\
\text { ity }\end{array}$} & \multicolumn{3}{|c|}{ Heat of solution } & \multicolumn{2}{|c|}{$\begin{array}{c}\text { Heat of } \\
\text { hydration }\end{array}$} \\
\hline & & & $\begin{array}{c}\text { Dry } \\
\text { cement }\end{array}$ & $\begin{array}{l}\text { 7-day } \\
\text { paste }\end{array}$ & $\begin{array}{l}\text { 28-day } \\
\text { paste }\end{array}$ & 7-day & $\begin{array}{c}28- \\
\text { day }\end{array}$ & & $\begin{array}{l}\text { Dry } \\
\text { cement }\end{array}$ & $\begin{array}{l}\text { 7-day } \\
\text { paste }\end{array}$ & $\begin{array}{l}\text { 28-day } \\
\text { paste }\end{array}$ & 7-day & $\begin{array}{l}28- \\
\text { day }\end{array}$ & & $\begin{array}{c}\text { Dry } \\
\text { cement }\end{array}$ & $\begin{array}{l}\text { 7-day } \\
\text { paste }\end{array}$ & $\begin{array}{l}\text { 28-day } \\
\text { paste }\end{array}$ & 7-day & $\begin{array}{l}28- \\
\text { day }\end{array}$ \\
\hline
\end{tabular}

ROUND 1

\begin{tabular}{|c|c|c|c|c|c|c|c|c|c|c|c|c|c|c|c|c|c|c|c|}
\hline a & $\left\{\begin{array}{l}\mathrm{a}_{\ldots} \ldots \ldots \\
\mathrm{b} \ldots \ldots\end{array}\right.$ & $\begin{array}{c}\text { cal/deg C } \\
394.3 \\
395.9 \\
396.9\end{array}$ & $\begin{array}{l}\mathrm{cal} / \mathrm{g} \\
598.0 \\
594.9 \\
596.2\end{array}$ & $\begin{array}{l}\mathrm{cal} / \mathrm{g} \\
533.9 \\
539.8 \\
541.8\end{array}$ & $\begin{array}{l}\mathrm{cal} / \mathrm{g} \\
522.0 \\
518.9 \\
519.3\end{array}$ & $\begin{array}{l}\mathrm{cal} / \mathrm{g} \\
64.1 \\
55.1 \\
54.4\end{array}$ & $\begin{array}{l}\mathrm{cal} / g \\
76.0 \\
76.0 \\
76.9\end{array}$ & $\begin{array}{c}\text { cal/deg } C \\
394.3 \\
394.3 \\
396.2\end{array}$ & $\begin{array}{l}\mathrm{cal} / \mathrm{g} \\
598.1 \\
594.6 \\
595.0\end{array}$ & $\begin{array}{l}\mathrm{cal} / \mathrm{g} \\
534.9 \\
539.6 \\
540.7\end{array}$ & $\begin{array}{l}\mathrm{cal} / \mathrm{g} \\
523.0 \\
518.7 \\
518.2\end{array}$ & $\begin{array}{l}\mathrm{cal} / \mathrm{g} \\
63.2 \\
55.0 \\
54.3\end{array}$ & $\begin{array}{l}\mathrm{cal} / \mathrm{g} \\
75.1 \\
75.9 \\
76.8\end{array}$ & $\begin{array}{c}\text { cal/deg C } \\
393.5 \\
395.0 \\
396.4\end{array}$ & $\begin{array}{l}\text { cal/g } \\
598.9 \\
595.4 \\
595.6\end{array}$ & $\begin{array}{l}\mathrm{cal} / \mathrm{g} \\
534.9 \\
538.7 \\
540.9\end{array}$ & $\begin{array}{l}\mathrm{cal} / \mathrm{g} \\
523.0 \\
519.8 \\
517.3\end{array}$ & $\begin{array}{l}\mathrm{cal} / \mathrm{g} \\
64.0 \\
56.7 \\
54.7\end{array}$ & $\begin{array}{l}c a l / g \\
75.9 \\
75.6 \\
78.3\end{array}$ \\
\hline & $\left\{\begin{array}{l}\mathrm{a}_{\ldots} \ldots \\
\mathrm{b}_{\ldots} \ldots \\
\mathrm{c}_{\ldots} \ldots\end{array}\right.$ & $\begin{array}{l}393.6 \\
395.1 \\
398.4\end{array}$ & $\begin{array}{l}599.7 \\
596.4 \\
596.0\end{array}$ & $\begin{array}{l}536.4 \\
540.7 \\
537.7\end{array}$ & $\begin{array}{l}519.1 \\
518.9 \\
520.3\end{array}$ & $\begin{array}{l}63.3 \\
55.5 \\
58.3\end{array}$ & $\begin{array}{l}80.6 \\
77.5 \\
77.7\end{array}$ & $\begin{array}{l}394.1 \\
394.5 \\
394.8\end{array}$ & $\begin{array}{l}600.6 \\
596.1 \\
594.8\end{array}$ & $\begin{array}{l}537.4 \\
540.7 \\
536.6\end{array}$ & $\begin{array}{l}520.0 \\
518.7 \\
519.2\end{array}$ & $\begin{array}{l}63.2 \\
55.4 \\
58.2\end{array}$ & $\begin{array}{l}80.6 \\
77.4 \\
75.6\end{array}$ & $\begin{array}{l}394.1 \\
395.1 \\
394.8\end{array}$ & $\begin{array}{l}600.6 \\
596.0 \\
595.1\end{array}$ & $\begin{array}{l}538.5 \\
541.9 \\
535.8\end{array}$ & $\begin{array}{l}520.0 \\
519.2 \\
519.3\end{array}$ & $\begin{array}{l}62.1 \\
54.1 \\
59.3\end{array}$ & $\begin{array}{l}80.6 \\
76.8 \\
75.8\end{array}$ \\
\hline & $\left\{\begin{array}{l}\mathrm{a}_{\ldots} \ldots \\
\mathrm{b}_{\ldots} \\
\mathrm{c}_{\ldots} . .\end{array}\right.$ & $\begin{array}{l}396.5 \\
396.9 \\
395.2\end{array}$ & $\begin{array}{l}598.3 \\
596.8 \\
598.9\end{array}$ & $\begin{array}{l}538.2 \\
539.1 \\
542.2\end{array}$ & $\begin{array}{l}519.1 \\
519.5 \\
523.5\end{array}$ & $\begin{array}{l}60.1 \\
57.7 \\
56.7\end{array}$ & $\begin{array}{l}79.2 \\
77.3 \\
75.4\end{array}$ & $\begin{array}{l}395.6 \\
396.2 \\
394.7\end{array}$ & $\begin{array}{l}599.4 \\
596.5 \\
597.7\end{array}$ & $\begin{array}{l}539.2 \\
539.0 \\
541.1\end{array}$ & $\begin{array}{l}520.0 \\
519.4 \\
522.3\end{array}$ & $\begin{array}{l}60.2 \\
57.5 \\
56.6\end{array}$ & $\begin{array}{l}79.4 \\
77.1 \\
75.4\end{array}$ & $\begin{array}{l}396.5 \\
396.9 \\
394.7\end{array}$ & $\begin{array}{l}599.4 \\
597.3 \\
597.8\end{array}$ & $\begin{array}{l}539.2 \\
539.7 \\
541.3\end{array}$ & $\begin{array}{l}518.8 \\
520.6 \\
522.6\end{array}$ & $\begin{array}{l}60.2 \\
57.6 \\
56.5\end{array}$ & $\begin{array}{l}80.6 \\
76.7 \\
75.2\end{array}$ \\
\hline
\end{tabular}

ROUND 2

\begin{tabular}{|c|c|c|c|c|c|c|c|c|c|c|c|c|c|c|c|c|c|c|c|}
\hline$a_{-}$ & $\left\{\begin{array}{l}a_{\ldots} \ldots \\
b_{\ldots} \ldots\end{array}\right.$ & $\begin{array}{l}395.3 \\
395.0 \\
393.0\end{array}$ & $\begin{array}{r}595.8 \\
599.9 \\
597.7\end{array}$ & $\begin{array}{l}536.8 \\
539.0 \\
536.2\end{array}$ & $\begin{array}{l}517.3 \\
515.6 \\
515.6\end{array}$ & $\begin{array}{l}59.0 \\
60.9 \\
61.5\end{array}$ & $\begin{array}{l}78.5 \\
84.3 \\
82.1\end{array}$ & $\begin{array}{l}394.9 \\
394.7 \\
394.6\end{array}$ & $\begin{array}{l}596.0 \\
599.6 \\
600.6\end{array}$ & $\begin{array}{l}537.1 \\
538.7 \\
535.5\end{array}$ & $\begin{array}{l}516.9 \\
514.9 \\
517.6\end{array}$ & $\begin{array}{l}58.9 \\
60.9 \\
65.1\end{array}$ & $\begin{array}{l}79.1 \\
84.7 \\
83.0\end{array}$ & $\begin{array}{l}394.1 \\
394.9 \\
394.6\end{array}$ & $\begin{array}{l}596.0 \\
599.8 \\
600.3\end{array}$ & $\begin{array}{l}537.1 \\
539.1 \\
536.0\end{array}$ & $\begin{array}{l}516.9 \\
515.6 \\
517.3\end{array}$ & $\begin{array}{l}58.9 \\
60.7 \\
64.3\end{array}$ & $\begin{array}{l}79.1 \\
84.2 \\
83.0\end{array}$ \\
\hline $\mathrm{b}_{-}$ & $\left\{\begin{array}{l}\mathrm{a}_{\mathrm{a}} \\
\mathrm{b}- \\
\mathrm{c}_{-}\end{array}\right.$ & $\begin{array}{l}394.5 \\
395.2 \\
395.3\end{array}$ & $\begin{array}{l}596.3 \\
595.1 \\
597.3\end{array}$ & $\begin{array}{l}535.2 \\
535.7 \\
536.0\end{array}$ & $\begin{array}{l}521.9 \\
520.5 \\
519.2\end{array}$ & $\begin{array}{l}61.1 \\
59.4 \\
61.3\end{array}$ & $\begin{array}{l}74.4 \\
74.6 \\
78.1\end{array}$ & $\begin{array}{l}394.1 \\
395.4 \\
395.5\end{array}$ & $\begin{array}{l}596.7 \\
596.6 \\
598.5\end{array}$ & $\begin{array}{l}537.5 \\
537.1 \\
536.7\end{array}$ & $\begin{array}{l}521.6 \\
520.1 \\
519.3\end{array}$ & $\begin{array}{l}59.2 \\
59.5 \\
61.8\end{array}$ & $\begin{array}{l}75.1 \\
76.5 \\
79.2\end{array}$ & $\begin{array}{l}394.9 \\
395.9 \\
394.8\end{array}$ & $\begin{array}{l}598.3 \\
596.0 \\
598.2\end{array}$ & $\begin{array}{l}533.3 \\
536.2 \\
536.5\end{array}$ & $\begin{array}{l}521.6 \\
520.2 \\
519.0\end{array}$ & $\begin{array}{l}65.0 \\
59.8 \\
61.7\end{array}$ & $\begin{array}{l}76.7 \\
75.8 \\
79.2\end{array}$ \\
\hline c. & $\left\{\begin{array}{l}\mathrm{a}_{\ldots} \\
\mathrm{b}_{\ldots} \\
\mathrm{c}_{\ldots}\end{array}\right.$ & $\begin{array}{l}395.0 \\
396.3 \\
394.8\end{array}$ & $\begin{array}{l}599.2 \\
598,4 \\
598.5\end{array}$ & $\begin{array}{l}540.7 \\
538.3 \\
533.5\end{array}$ & $\begin{array}{l}518.2 \\
518.1 \\
517.7\end{array}$ & $\begin{array}{l}58.5 \\
60.1 \\
65.0\end{array}$ & $\begin{array}{l}81.0 \\
80.3 \\
80.8\end{array}$ & $\begin{array}{l}394.6 \\
394.6 \\
393.1\end{array}$ & $\begin{array}{l}595.7 \\
598.3 \\
599.6\end{array}$ & $\begin{array}{l}542.3 \\
538.5 \\
533.9\end{array}$ & $\begin{array}{l}519.3 \\
517.8 \\
517.5\end{array}$ & $\begin{array}{l}53.4 \\
59.8 \\
65.7\end{array}$ & $\begin{array}{l}76.4 \\
80.5 \\
82.1\end{array}$ & $\begin{array}{l}394.6 \\
394.7 \\
393.1\end{array}$ & $\begin{array}{l}599.1 \\
598.6 \\
599.3\end{array}$ & $\begin{array}{l}541.0 \\
538.4 \\
535.5\end{array}$ & $\begin{array}{l}518.3 \\
518.3 \\
517.0\end{array}$ & $\begin{array}{l}58.1 \\
60.2 \\
63.8\end{array}$ & $\begin{array}{l}80.8 \\
80.3 \\
82.3\end{array}$ \\
\hline
\end{tabular}

a Heat of solution calculated according to Federal Specification SS-C-158b.

$\checkmark$ Heat of solution calculated from the temperature of the calorimeter at zero time, $20 \mathrm{~min}$, and $40 \mathrm{~min}$.

- Heat of solution calculated from the temperature of the calorimeter at zero time, $25 \mathrm{~min}$, and $50 \mathrm{~min}$.

$d$ Calculated from differences in the heats of solution of corresponding dry cements and hydrated pastes.

The data were subjected to a complete analysis of variance. Information was sought as to the reproducibility of the methods of test, the variation among the operators, and the deviations introduced by the reduced-observation methods.

The uncertainty of an individual determination of the heat of solution is shown in table 2. There is evidence [3] to suggest that the heat of solution of dry cement changes when the container is opened even briefly. To eliminate the possible influence of this phenomenon on the correlation of the heats of solution of the hydrated pastes, the data were arranged in groups of three in the order shown in table 1. Each member of a set of three was determined on pastes mixed on a single day. From the data of table 1 the standard deviations of individual determinations of the heats of solution of the dry cement and of the 7- and 28-day hydrates were calculated and are shown in table 2 . It will be noted that the uncertainty of the determination made with the 7-day hydrated paste is distinctly larger than either of the others. This is possibly due to a more rapid gain of $\mathrm{CO}_{2}$ from the atmosphere and loss of water through evaporation by this paste during grinding.
TABLE 2. Reproducibility of heat-of-solution tests

\begin{tabular}{|c|c|c|c|}
\hline \multirow{2}{*}{ Method } & \multicolumn{3}{|c|}{$\begin{array}{l}\text { Standard deviation a of an indi- } \\
\text { vidual test }\end{array}$} \\
\hline & $\begin{array}{c}\text { Dry } \\
\text { cement }\end{array}$ & $\begin{array}{l}\text { 7-day } \\
\text { paste }\end{array}$ & $\begin{array}{c}\text { 28-day } \\
\text { paste }\end{array}$ \\
\hline $\begin{array}{l}\text { Specification b } \\
0-20-400^{\circ} \\
0-25-500^{\circ}\end{array}$ & $\begin{array}{l}\text { cal/g } \\
1.5 \\
1.1 \\
1.4\end{array}$ & $\begin{array}{l}c a l / g \\
2.7 \\
2.5 \\
2.3\end{array}$ & $\begin{array}{l}\mathrm{cal} / \mathrm{g} \\
1.4 \\
1.5 \\
1.6\end{array}$ \\
\hline
\end{tabular}

a Standard deviation, $\sigma$,

$$
=\sqrt{\frac{\sum_{(1)}^{(6)} \frac{\sum^{3}(X-\bar{X})^{2}}{2}}{6}}
$$

where the summation (1) to (6) refers to mixes by $\mathrm{A}, \mathrm{B}$, and $\mathrm{C}$ in rounds 1 and 2 , and the summation 1 to 3 refers to the individual determinations within a mix by $A, B$, etc. $X$ is the value of the single determination, and $\bar{X}$ is the average value of the group of three.

$b$ Heat of solution calculated by the method described in Federal Specification SS-C-158b.

c These are reduced-observation methods of calculating the heat of solution from readings taken at zero time, $20 \mathrm{~min}$, and $40 \mathrm{~min}$, and at zero time, $25 \mathrm{~min}$, and $50 \mathrm{~min}$, respectively. 
From the standard deviations of the heat-ofsolution determinations in table 2 , a predicted value can be calculated for the uncertainty of the heat of hydration. In table 3 are shown predicted values and actual values of the standard deviation of the heat of hydration. The predicted and the observed values are generally in good agreement. An exception is to be noted in the observed value for 7-day pastes calculated by the 0-20-40 method. The precision is somewhat less than that assumed earlier for purposes of discussion. It is apparent from table 2 that the variability of the 7-day determination is responsible.

TABLE 3. Predicted and observed reproducibility of heat-ofhydration measurements of portland cement

\begin{tabular}{|c|c|c|c|}
\hline \multirow{2}{*}{$\begin{array}{c}\text { Tested } \\
\text { at- }\end{array}$} & \multicolumn{3}{|c|}{ Standard deviation } \\
\hline & Method a & $\begin{array}{c}\text { Pre- } \\
\text { dicted b }\end{array}$ & $\begin{array}{c}\text { Ob- } \\
\text { served }\end{array}$ \\
\hline 7 days... & $\left\{\begin{array}{l}\text { Specification } \\
0-20-40 \\
0-25-50\end{array}\right.$ & $\begin{array}{c}\mathrm{cal} / \mathrm{g} \\
3.1 \\
2.7 \\
2.7\end{array}$ & $\begin{array}{c}\mathrm{cal} / \mathrm{g} \\
3.2 \\
3.9 \\
3.2\end{array}$ \\
\hline 28 days... & $\left\{\begin{array}{l}\text { Specification } \\
0-20-40 \\
0-25-50\end{array}\right.$ & $\begin{array}{l}2.1 \\
1.9 \\
2.1\end{array}$ & $\begin{array}{l}2.0 \\
2.3 \\
2.2\end{array}$ \\
\hline
\end{tabular}

a The method of calculation of the heats of solution were according to the Federal Specification SS-C-158b: and from the temperature readings taken at zero time, $20 \mathrm{~min}$, and $40 \mathrm{~min}$; and at zero time, $25 \mathrm{~min}$, and $50 \mathrm{~min}$, respectively. zero time, $20 \mathrm{~min}$, and $40 \mathrm{~min}$; and at zero time, $25 \mathrm{~min}$, and $50 \mathrm{~min}$, respectively. individual tests by the formula:

$$
\text { standard deviation }(\text { predicted })=\sqrt{\sigma^{2} \text { dry }+\sigma^{2}\lfloor\text { ydrated. }}
$$

c Calculated from the individual differences between the heats of solution of the dry cements and the hydrated pastes given in table 1 by the formula:

$$
\text { standard deviation (observed) }=\sqrt{\frac{\sum_{(1)}^{(6)} \frac{\sum_{1}^{3}(X-\bar{X})^{2}}{2}}{6}}
$$

where the summation (1) to (6) refers to mixes by $\mathrm{A}, \mathrm{B}$, and $\mathrm{C}$ in rounds 1 and 2 and the summation 1 to 3 refers to the individual determinations within a mix. $X$ is the value for a single determination, and $\bar{X}$ is the average of the mix.

The operators can be compared accurately only on the results obtained with dry cement and during calibrations, as each operator had a different paste for the tests with hydrated cement. In table 4 are shown the standard deviations calculated for the individual operators and for the test when considering all operators. To facilitate comparison, the coefficients of variation have also been calculated. The heat-capacity determinations are slightly less precise than the heat-of-solution measurements, as judged from the coefficients of variation. The differences shown in table 4 are insignificant, but it was expected that any difference would be in favor of the calibrations. The zinc oxide, of analyticalreagent quality, is freshly heated before each determination, whereas the dry cement is subject to attack by whatever moisture and $\mathrm{CO}_{2}$ enters the container during removal of test samples or between tests. In table 5 are shown the averages of six determinations by each operator on dry cement and on hydrated pastes at 7 and 28 days. There is, in tables 4 and 5, no indication of significant differences among the operators either in bias or precision. The agreement among the results is as close as would be expected if all the determinations had been made by the same operator. This is true in spite of the differences in the operators' experience.

\begin{tabular}{|c|c|c|c|c|c|c|}
\hline \multirow{2}{*}{ Operator } & \multicolumn{3}{|c|}{ Standard deviation $a$} & \multicolumn{3}{|c|}{ Coefficient of variation $b$} \\
\hline & $\begin{array}{l}\text { Specifi- } \\
\text { cation }\end{array}$ & $0-20-40$ & $0-25-50$ & $\begin{array}{l}\text { Specifi- } \\
\text { cation }\end{array}$ & $0-20-40$ & $0-25-50$ \\
\hline \multicolumn{7}{|c|}{ HEAT CAPACITY MEASUREMENTS } \\
\hline $\begin{array}{l}\mathrm{a}_{\ldots} \ldots . . \\
\mathrm{b}_{\ldots} . . . \\
\mathrm{c}_{\ldots}\end{array}$ & $\begin{array}{c}\text { cal/deg } C \\
1.1 \\
0.8 \\
1.4\end{array}$ & $\begin{array}{c}\text { cal/deg } C \\
0.6 \\
.8 \\
1.0\end{array}$ & $\begin{array}{c}\text { cal/deg } C \\
1.2 \\
0.9 \\
.9\end{array}$ & $\begin{array}{r}\% \\
0.28 \\
.20 \\
.35\end{array}$ & $\begin{array}{c}\% \\
0.15 \\
.20 \\
.25\end{array}$ & $\begin{array}{c}\% \\
0.30 \\
.23 \\
.23\end{array}$ \\
\hline All c... & 1. 1 & 0.8 & 1.0 & .28 & .20 & .25 \\
\hline \multicolumn{7}{|c|}{ HEAT OF SOLUTION OF DRY CEMENT } \\
\hline $\begin{array}{l}\mathrm{a}_{\ldots} \ldots \\
\mathrm{b} \\
\mathrm{c} \ldots \ldots\end{array}$ & $\begin{array}{c}c a l / g \\
1.4 \\
1.9 \\
1.2\end{array}$ & $\begin{array}{c}\mathrm{cal} / \mathrm{g} \\
0.7 \\
1.3 \\
1.4\end{array}$ & $\begin{array}{c}c a l / g \\
1.3 \\
1.5 \\
1.3\end{array}$ & $\begin{array}{r}0.23 \\
.32 \\
.20\end{array}$ & $\begin{array}{r}0.12 \\
.22 \\
.23\end{array}$ & $\begin{array}{r}0.22 \\
.25 \\
.22\end{array}$ \\
\hline All $c \ldots$ & 1.5 & 1.1 & 1.4 & .25 & .20 & .23 \\
\hline
\end{tabular}

TABLE 4. Comparison of operator's precision

a Standard deviation, $\sigma$,

$$
=\sqrt{\frac{\sum_{1}^{3}\left(X_{1}-\bar{X}_{1}\right)^{2}}{2}+\frac{\sum_{1}^{3}\left(X_{2}-\bar{X}_{2}\right)^{2}}{2}},
$$

where the summation 1 to 3 refers to determinations by the operator in a single where the summation 1 to 3 refers to determinations by the operator in a single
round, the subscript refers to round 1 or round $2, X$ indicates individual determinations, and $\bar{X}$ indicates the average value of the determination for the round and operator indicated.

$b$ The coefficient of variation is the ratio of the standard deviation to the average value of the determinations involved, expressed as percentage.

$c$ The standard deviation for all of the operators is equal to

$$
\sqrt{\frac{\sigma_{a}^{2}+\sigma_{b}^{2}+\sigma_{c}^{2}}{3}}
$$


TABLE 5. Heat capacities and heats of solution and hydration

[Average of six determinations by each operator]

\begin{tabular}{|c|c|c|c|}
\hline \multirow{2}{*}{ Operator } & \multicolumn{3}{|c|}{ Method } \\
\hline & $\begin{array}{l}\text { Specifica- } \\
\text { tion }^{\mathrm{a}}\end{array}$ & $0-20-40$ b & $0-25-50$ b \\
\hline \multicolumn{4}{|c|}{ HEAT CAPACITY OF THE CALORIMETER } \\
\hline $\begin{array}{l}\mathrm{a} \\
\mathrm{b} \\
\mathrm{c}\end{array}$ & $\begin{array}{r}\text { cal/deg } C \\
394.8 \\
395.8 \\
395.5\end{array}$ & $\begin{array}{r}\text { cal/deg } C \\
394.6 \\
395.0 \\
394.8\end{array}$ & $\begin{array}{r}\text { cal/deg } C \\
394.6 \\
395.4 \\
394.8\end{array}$ \\
\hline $\begin{array}{l}\text { Range } \\
\text { Expected range } \mathrm{c}\end{array}$ & $\begin{array}{l}1.0 \\
1.1\end{array}$ & $\begin{array}{l}0.4 \\
0.8\end{array}$ & $\begin{array}{l}0.8 \\
1.0\end{array}$ \\
\hline \multicolumn{4}{|c|}{ HEAT OF SOLUTION, DRY CEMENT } \\
\hline $\begin{array}{l}\mathrm{a}_{\ldots} \\
\mathrm{b}_{-} \\
\mathrm{c}_{-}\end{array}$ & $\begin{array}{l}\mathrm{cal} / \mathrm{g} \\
597.9 \\
596.9 \\
597.4\end{array}$ & $\begin{array}{l}\mathrm{cal} / \mathrm{g} \\
597.9 \\
597.0 \\
597.7\end{array}$ & $\begin{array}{r}\text { cal } / g \\
598.7 \\
597.2 \\
597.7\end{array}$ \\
\hline Range .............. & 1.0 & 0.9 & 1.5 \\
\hline Expected range ${ }^{c} \ldots$ & 1.6 & 1.1 & 1.4 \\
\hline \multicolumn{4}{|c|}{ HEAT OF SOLUTION, 7-DAY PASTE } \\
\hline & 536.9 & 537.8 & 537.3 \\
\hline $\mathrm{b}$ & $\begin{array}{l}538.8 \\
537.9\end{array}$ & $\begin{array}{l}538.9 \\
537.4\end{array}$ & $\begin{array}{l}539.1 \\
537.7\end{array}$ \\
\hline Range & 1.9 & 1.5 & 1.8 \\
\hline Expected range ${ }^{c} \ldots$ & 2.8 & 2. 6 & 2.4 \\
\hline \multicolumn{4}{|c|}{ HEAT OF SOLUTION, 28-DAY PASTE } \\
\hline a. & 519.6 & 520.1 & 519.8 \\
\hline & 518.6 & 518. 3 & 519.0 \\
\hline $\mathrm{c} \ldots$ & 519.3 & 519.0 & 518.8 \\
\hline Range & 1.0 & 1.8 & 1. 6 \\
\hline Expected range ${ }^{\circ} \ldots$ & 1.5 & 1. 6 & 1.7 \\
\hline \multicolumn{4}{|c|}{ HEAT OF HYDRATION AT 7 DAYS } \\
\hline $\begin{array}{l}\mathrm{a} \\
\mathrm{b} \\
\mathrm{c}\end{array}$ & $\begin{array}{l}61.0 \\
58.1 \\
59.5\end{array}$ & $\begin{array}{l}59.7 \\
58.0 \\
60.3\end{array}$ & $\begin{array}{l}61.4 \\
58.2 \\
60.0\end{array}$ \\
\hline $\begin{array}{l}\text { Range } \\
\text { Expected range }\end{array}$ & $\begin{array}{l}2.9 \\
3.3\end{array}$ & $\begin{array}{l}\text { 1. } 7 \\
\text { 4. } 0\end{array}$ & $\begin{array}{l}\text { 3. } 2 \\
3.3\end{array}$ \\
\hline \multicolumn{4}{|c|}{ HEAT OF HYDRATION AT 28 DAYS } \\
\hline$\ldots$ & 78. 3 & 77. 6 & 79.0 \\
\hline 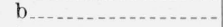 & 78.4 & 78.7 & 78. 2 \\
\hline e. & 78.5 & 78.7 & 79.0 \\
\hline Range............ & 0.2 & 1.1 & 0.8 \\
\hline Expected range ${ }^{c} \ldots$ & 2.1 & 2.4 & 2.3 \\
\hline
\end{tabular}

a Calculated according to Federal Specification SS-C-158b

b These are reduced-observation methods of calculating the heat of solution from calorimeter-temperature readings taken at zero time, $20 \mathrm{~min}$, and $40 \mathrm{~min}$, and at zero time, $25 \mathrm{~min}$, and $50 \mathrm{~min}$.

- Expected range for the average of six is equal to $2.534 \frac{\sigma}{\sqrt{6}}$, where $\sigma$ is the standard deviation of an individual determination (given in table 2 for heat of solution tests, in table 4 for heat capacities, and in table 3 for observed heats of hydration).

By regrouping the data in table 1 , the effect of different operators as mixers can be tested. This was done, and table 6 shows the results. The averages are in good agreement, showing that the differences between mixers are not significant.
TABLE 6. Heats of solution of hydrated cement pastes

[Average of six specimens prepared by each mixer]

\begin{tabular}{|c|c|c|c|}
\hline \multirow{2}{*}{ Mixer } & \multicolumn{3}{|c|}{ Method } \\
\hline & $\begin{array}{l}\text { Specifica- } \\
\text { tion }{ }^{a}\end{array}$ & $0-20-40$ b & $0-25-50$ b \\
\hline \multicolumn{4}{|c|}{ HEATS OF SOLUTION, 7-DAY PASTES } \\
\hline $\begin{array}{l}a_{\ldots} . . . \\
b_{-. .-} \\
c_{-\ldots}\end{array}$ & $\begin{array}{l}\mathrm{cal} / \mathrm{g} \\
537.9 \\
537.0 \\
538.7\end{array}$ & $\begin{array}{r}\mathrm{cal} / \mathrm{g} \\
537.7 \\
537.4 \\
539.0\end{array}$ & $\begin{array}{r}\text { cal/g } \\
537.8 \\
537.0 \\
539.3\end{array}$ \\
\hline Range & 1.7 & 1. 6 & 2.3 \\
\hline \multicolumn{4}{|c|}{ HEATS OF SOLUTION, 28-DAY PASTES } \\
\hline $\begin{array}{l}\mathrm{a} \ldots \ldots \\
\mathrm{b} \ldots \ldots \\
\mathrm{c} \ldots \ldots\end{array}$ & $\begin{array}{l}518.1 \\
520.5 \\
519.3\end{array}$ & $\begin{array}{l}518.2 \\
519.8 \\
519.4\end{array}$ & $\begin{array}{l}518.3 \\
519.9 \\
519.3\end{array}$ \\
\hline $\begin{array}{l}\text { Range } \\
\text { Expected range }\end{array}$ & $\begin{array}{l}2.4 \\
1.5\end{array}$ & $\begin{array}{l}1.6 \\
1.6\end{array}$ & $\begin{array}{l}1.6 \\
1.7\end{array}$ \\
\hline
\end{tabular}

a Heat of solution calculated according to Federal Specification SS-C-158b. b Heat of solution calculated from calorimeter temperature readings made at zero time, $20 \mathrm{~min}$, and $40 \mathrm{~min}$; and at zero time, $25 \mathrm{~min}$, and $50 \mathrm{~min}$; respectively. e From table 5 .

It was found unexpectedly that the heats of solution of the pastes determined during the second round were lower than those determined during the first. For round one, cement was taken from the containers on July 7,8 , and 14 , to mix the pastes. For round two, the dates were July 20, 21, and 22 . The dry-cement determinations were made on July 12,13 , and 21 for the first round and on July 22, 25, and 26 for the second. At these times the containers were opened.

In table 7 are shown the results of calculations made on the tests grouped by rounds. In every case

TABLE 7. Heats of solution

[A verage for all operators for separate rounds]

\begin{tabular}{|c|c|c|c|c|c|c|c|c|c|}
\hline & \multicolumn{9}{|c|}{ Method a } \\
\hline & \multicolumn{3}{|c|}{ Specification } & \multicolumn{3}{|c|}{$0-20-40$} & \multicolumn{3}{|c|}{$0-25-50$} \\
\hline & $\begin{array}{c}\text { Dry } \\
\text { ce- } \\
\text { ment }\end{array}$ & \begin{tabular}{|c|} 
7-day \\
paste
\end{tabular} & $\begin{array}{c}28- \\
\text { day } \\
\text { paste }\end{array}$ & $\begin{array}{c}\text { Dry } \\
\text { ce- } \\
\text { ment }\end{array}$ & $\begin{array}{l}\text { 7-day } \\
\text { paste }\end{array}$ & $\begin{array}{c}28- \\
\text { day } \\
\text { paste }\end{array}$ & $\begin{array}{c}\text { Dry } \\
\text { ce- } \\
\text { ment }\end{array}$ & $\begin{array}{l}\text { 7-day } \\
\text { paste }\end{array}$ & $\begin{array}{l}28- \\
\text { day } \\
\text { paste }\end{array}$ \\
\hline $\begin{array}{l}\text { Round 1 } \\
\text { Round 2 }\end{array}$ & $\begin{array}{l}c a l / g \\
597.2 \\
597.6\end{array}$ & $\begin{array}{l}\text { callg } \\
538.9 \\
536.8\end{array}$ & $\begin{array}{l}c a l / g \\
520.1 \\
518.2\end{array}$ & $\begin{array}{l}c a l / g \\
597.1 \\
597.9\end{array}$ & $\begin{array}{l}\text { cal/g } \\
538.8 \\
537.3\end{array}$ & $\begin{array}{l}c a l / g \\
519.9 \\
518.3\end{array}$ & $\begin{array}{l}\text { cal/g } \\
597.3 \\
598.4\end{array}$ & $\begin{array}{l}\mathrm{cal} / \mathrm{g} \\
539.0 \\
537.1\end{array}$ & $\begin{array}{l}\text { cal/g } \\
520.1 \\
518.2\end{array}$ \\
\hline $\begin{array}{l}\text { Difference (round } \\
\text { 1-round 2) }\end{array}$ & -0.4 & $\begin{array}{r}000.0 \\
2.1\end{array}$ & $\begin{array}{r}510.2 \\
1.9\end{array}$ & $\begin{array}{r}037.0 \\
0.8\end{array}$ & $\begin{array}{r}031.0 \\
1.5\end{array}$ & $\begin{array}{r}010.0 \\
1.6\end{array}$ & -1.1 & 1.9 & 1.9 \\
\hline $\begin{array}{l}\text { Standard deviation } \\
\text { of difference }\end{array}$ & $\begin{array}{r}.5 \\
.8\end{array}$ & $\begin{array}{r}0.9 \\
* 2.3\end{array}$ & $\begin{array}{r}1.0 \\
0.5 \\
* 3.8\end{array}$ & $\begin{array}{r}.4 \\
2.0\end{array}$ & $\begin{array}{l}0.8 \\
1.9\end{array}$ & $\begin{array}{r}0.5 \\
* 3.2\end{array}$ & $\begin{array}{l}0.5 \\
2.2\end{array}$ & $\begin{array}{r}0.8 \\
* 2.4\end{array}$ & $\begin{array}{l}0.5 \\
* 3.8\end{array}$ \\
\hline
\end{tabular}

a Heats of solution calculated according to Federal Specification; from calorimeter temperatures at zero time, $20 \mathrm{~min}$, and $40 \mathrm{~min}$; and from calorimeter temperatures at zero time, $25 \mathrm{~min}$, and $50 \mathrm{~min}$; respectively.

$b$ Standard deviation of the difference is equal to:

$$
\frac{\sqrt{2}}{\sqrt{18}} \sigma ; \sigma \text { from table } 2 .
$$

$c t=$ difference divided by the standard deviation of the difference. The 5-percent level of significance is 2.2. Differences exceeding this value are marked with an asterisk. 
the average heat of solution of the hardened paste is less for the second round of tests than for the first. With one exception, this difference appears to be real for each age and for each method of calculation. The average value of the heat of solution of the dry cement was higher for the second round than for the first, the difference in one case approaching significance. This difference is in the wrong direction to be the effect of $\mathrm{CO}_{2}$ and $\mathrm{H}_{2} \mathrm{O}$, apparently the only available agents, and must be considered accidental.

Up to this point, the determination of the ignition residues of the cement and cement pastes has not been discussed. Every heat-of-solution determination depends on a companion determination of the ignition residue of the calorimeter sample. When the hardened paste is removed from the sealed vial and ground, part of the water is lost, and $\mathrm{CO}_{2}$ is absorbed from the atmosphere. The extent of these changes depends on the temperature, humidity, and $\mathrm{CO}_{2}$ content of the air as well as on the length of time the sample is exposed during grinding. The loss of water affects mainly the ignited weight of the calorimeter sample, but the absorption of $\mathrm{CO}_{2}$ results in a reduction in the heat of solution, as the heat of solution of $\mathrm{CaCO}_{3}$ is markedly less than that of $\mathrm{Ca}(\mathrm{OH})_{2}$. Carlson and Forbrich [5] have discussed the drying and carbonation of the hydrated paste in considerable detail.

The ignition-residue data obtained in these tests were analyzed in the same manner as the heat-ofsolution data. The average ratios of ignited residue to sample taken were $0.9807,0.7218$, and 0.7189 for the dry cement, the 7-day paste, and the 28-day paste, respectively. The standard deviation of a single determination for the corresponding samples was $0.0008,0.0050$, and 0.0029 . The theoretical ratio for the pastes mixed from this cement is 0.7005 . Experiment has shown that there is negligible loss of water from the pastes while stored in the sealed vials. It is apparent that appreciable water was lost during mixing or grinding. The statistical analysis shows no significant differences among the operators either in mixing the paste or in determining the ignition residue of the dry cement. There were differences, perhaps significant, among the values obtained by the operators on the hydrated pastes. The largest difference, however, was between the average residue at 7 days found in the first round and that found in the second. The average values were 0.7179 and 0.7256 , respectively, and the $t$-value (see table 7 , footnote c) was calculated to be 4.5. At 28 days it was only 0.9 . This indicates that there was a real and significant difference in the grinding of the pastes for rounds 1 and 2, although there was perhaps none at 28 days.

When the heats of solution of the 7-day secondround hydrates were being determined, the room temperature rose from $30^{\circ}$ to $34^{\circ} \mathrm{C}$ during the working days. This occurred at a comparatively uniform rate of about $0.5 \mathrm{deg} \mathrm{C} / \mathrm{hr}$. When the heats of solution of the 7-day first-round hydrates were being determined, the daily temperature range was from $27^{\circ}$ to $30^{\circ} \mathrm{C}$ on the first two days and from $30^{\circ}$ to $32^{\circ} \mathrm{C}$ on the third. During the determination of the heats of solution of the 28-day hydrates, the room temperature varied between $24^{\circ}$ and $26^{\circ} \mathrm{C}$. The higher average temperature for the secondround hydrates probably caused greater loss of water during grinding and hence the higher values for the residue on ignition. This difference in water loss and room temperature may have caused the lower heats of solution of the 7-day pastes in the second round, although no such difference in either room temperature or ignited residue occurred in the 28day tests, in which the first-round heats of solution also exceeded those of the second round by a significant amount.

There appears to be no significant difference in the values obtained for the heats of solution whether calculated by the specification method or from the same data by either of the reduced-observation methods. From an examination of the tables, it seems also clear that on the basis of precision there is no choice among the three methods of calculation. Either of the shorter methods of calculation should give acceptable results. Because of the possibility that some cements may dissolve more slowly than that used in this study, there may be an advantage

TABLE 8. Heats of hydration of routine samples

\begin{tabular}{|c|c|c|c|c|c|c|c|}
\hline \multirow{3}{*}{ Brand } & \multirow{3}{*}{$\mathrm{Bin}$} & \multicolumn{3}{|c|}{ At 7 days } & \multicolumn{3}{|c|}{ At 28 days } \\
\hline & & \multicolumn{6}{|c|}{ Method a } \\
\hline & & $\begin{array}{l}\text { Specifi- } \\
\text { cation }\end{array}$ & $0-20-40$ & $0-25-50$ & $\begin{array}{l}\text { Specifi- } \\
\text { cation }\end{array}$ & $0-20-40$ & $0-25-50$ \\
\hline A & 1 & $\left\{\begin{array}{c}c a l / g \\
58 \\
58 \\
58\end{array}\right.$ & $\begin{array}{c}\mathrm{cal} / \mathrm{g} \\
53 \\
54 \\
53\end{array}$ & $\begin{array}{c}\mathrm{cal} / \mathrm{g} \\
58 \\
58 \\
58\end{array}$ & $\begin{array}{l}c a l / g \\
78 \\
78 \\
82\end{array}$ & $\begin{array}{l}\mathrm{cal} / \mathrm{g} \\
73 \\
74 \\
71\end{array}$ & $\begin{array}{l}c a l / g \\
78 \\
78 \\
75\end{array}$ \\
\hline B & 1 & $\left\{\begin{array}{l}51 \\
50 \\
52 \\
54 \\
56\end{array}\right.$ & $\begin{array}{l}56 \\
51 \\
54 \\
54 \\
58\end{array}$ & $\begin{array}{l}56 \\
51 \\
54 \\
54 \\
57\end{array}$ & $\begin{array}{l}73 \\
66 \\
68 \\
72 \\
76\end{array}$ & $\begin{array}{l}74 \\
66 \\
69 \\
72 \\
76\end{array}$ & $\begin{array}{l}74 \\
67 \\
69 \\
72 \\
75\end{array}$ \\
\hline B & 2 & $\begin{array}{l}56 \\
59 \\
63 \\
58 \\
61 \\
63\end{array}$ & $\begin{array}{l}56 \\
61 \\
64 \\
55 \\
61 \\
64\end{array}$ & $\begin{array}{l}56 \\
59 \\
62 \\
53 \\
60 \\
63\end{array}$ & $\begin{array}{l}72 \\
74 \\
79 \\
75 \\
76 \\
78\end{array}$ & $\begin{array}{l}72 \\
74 \\
79 \\
76 \\
78 \\
80\end{array}$ & $\begin{array}{l}73 \\
74 \\
78 \\
75 \\
77 \\
78\end{array}$ \\
\hline $\mathrm{C}$ & 1 & $\begin{array}{l}60 \\
59 \\
61 \\
64 \\
57 \\
60 \\
62\end{array}$ & $\begin{array}{l}58 \\
56 \\
60 \\
63 \\
60 \\
58 \\
60\end{array}$ & $\begin{array}{l}59 \\
60 \\
61 \\
63 \\
58 \\
60 \\
63\end{array}$ & $\begin{array}{l}76 \\
75 \\
76 \\
77 \\
74 \\
76 \\
79\end{array}$ & $\begin{array}{l}76 \\
71 \\
77 \\
77 \\
78 \\
77 \\
78\end{array}$ & $\begin{array}{l}75 \\
73 \\
77 \\
76 \\
76 \\
77 \\
80\end{array}$ \\
\hline D & 1 & $\begin{array}{l}61 \\
58 \\
60 \\
57 \\
60 \\
58 \\
61 \\
52 \\
62 \\
58 \\
57\end{array}$ & $\begin{array}{l}62 \\
59 \\
60 \\
68 \\
58 \\
59 \\
60 \\
58 \\
63 \\
59 \\
59\end{array}$ & $\begin{array}{l}62 \\
60 \\
61 \\
58 \\
58 \\
58 \\
60 \\
56 \\
63 \\
58 \\
59\end{array}$ & $\begin{array}{l}77 \\
73 \\
79 \\
76 \\
78 \\
76 \\
80 \\
77 \\
78 \\
80 \\
77\end{array}$ & $\begin{array}{l}74 \\
70 \\
75 \\
75 \\
76 \\
75 \\
76 \\
74 \\
75 \\
76 \\
76\end{array}$ & $\begin{array}{l}73 \\
69 \\
75 \\
75 \\
74 \\
72 \\
76 \\
73 \\
74 \\
76 \\
76\end{array}$ \\
\hline \multirow{2}{*}{\multicolumn{2}{|c|}{$\begin{array}{l}\text { A verage } \\
\text { A verage difference } \\
\text { from specification }\end{array}$}} & 58. 2 & 58.6 & 58.6 & 76.0 & 74.7 & 74.6 \\
\hline & & & 2.3 & 1.2 & -...... & 2. 1 & 2. 0 \\
\hline
\end{tabular}

s Heats of solution were calculated (a) according to Federal Specification SS-C-158b, (b) from the calorimeter temperature at zero time, $20 \mathrm{~min}$, and 40 min., and (c) from the calorimeter temperature at zero time, $25 \mathrm{~min}$, and 50 min. 
in using the method having observations made at 25 or 50 min after the beginning of the solution test.

In table 8 are shown the heats of hydration determined in the routine testing of five bins of cement of four different brands. The average heat of hydration of thirty two samples is $0.4 \mathrm{cal} / \mathrm{g}$ lower at 7 days and about $1 \mathrm{cal} / \mathrm{g}$ higher at 28 days when calculated by the specification method than when calculated by either of the others. At 7 days the average deviation (without regard to sign) of the 0-25-50 method from the specification method is about half of the 0-20-40 method. At 28 days the average deviations are about the same, for either of the reduced-observation methods, about $2 \mathrm{cal} / \mathrm{g}$. A difference in the behavior of the cement or in the operation of the calorimeter is evidenced by the much larger deviations for the fourth brand.

\section{Summary}

A study was made of the precision of the heat-ofsolution test for determining the heat of hydration of portland cement. Three operators participated in making six determinations each of the heat of hydration of a single portland cement sample. The results of their measurements were calculated by the specification method and by two reduced-observation methods, and a complete analysis was made of the variance of the data. It was found that there were no significant differences among these measurements obtained by three operators and that the reducedobservation methods each gave acceptable results in these special tests. The agreement among the meth- ods of calculation was somewhat poorer when they were applied to routine tests. The special tests indicate that the heat of hydration of portland cement can be determined by the heat-of-solution method with a precision of about $3 \mathrm{cal} / \mathrm{g}$ at 7 days and about $2 \mathrm{cal} / \mathrm{g}$ at 28 days. Somewhat better precision may be attained by experienced operators.

The heat-of-solution tests were made by R. B. Peppler, E. D. West, and J. V. Gilfrich. The statistical analysis was performed by W. J. Youden and J. M. Cameron, who also assisted in designing the experiment. The author is deeply indebted to them for their interest and assistance in this project.

\section{References}

[1] Federal Specification for cements, hydraulic; general specifications (methods for sampling, inspection, and testing) SS-C-158b (May 20, 1946).

[2] Standard method of test for heat of hydration of portland cement. American Society for Testing Materials Designation $\mathrm{C}-186-47$ (Oct. 15, 1947).

[3] L. Shartsis and E. S. Newman, A study of the heat-ofsolution procedure for determining the heat of hydration of portland cement, Proc. Am. Soc. Testing Materials 43, 905 (1943).

[4] Federal Specification for cements, hydraulic; general specifications (methods for sampling, inspection, and testing) SS-C-158 (Sept. 30, 1936).

[5] R. W. Carlson and L. R. Forbrich, Correlation of methods of measuring heat of hydration of cement, Ind. Eng. Chem. 10, 382 (1938).

Washington, June 1, 1950. 